\title{
Interactions in the ternary reciprocal system $\mathrm{Tl}_{2} \mathrm{~S}+\mathrm{SnTe} \leftrightarrow \mathrm{Tl}_{2} \mathrm{Te}+\mathrm{SnS}$
}

\author{
M.J. FILEP ${ }^{1 *}$, M.Yu. SABOV ${ }^{1}$, I.E. BARCHIY ${ }^{1}$, K.J. PLUCINSKI ${ }^{2}$, A.M. SOLOMON ${ }^{3}$ \\ ${ }^{1}$ Faculty of Chemistry, Uzhhorod National University, Pidhirna St. 46, 88000 Uzhhorod, Ukraine \\ ${ }^{2}$ Department of Electronics, Military University of Technology, Kaliskiego 2, 00-908 Warsaw, Poland \\ ${ }^{3}$ Institute of Electron Physics, Universytetska St. 21, 88017 Uzhhorod, Ukraine \\ * Corresponding author. Tel.: +380-312-237163; fax: +380-312-235091; e-mail: mfilep23@mail.ru
}

Received September 20, 2013; accepted December 25, 2013; available on-line August 30, 2014

The phase diagram of the ternary reciprocal system $\mathrm{Tl}_{2} \mathrm{~S}+\mathrm{SnTe} \leftrightarrow \mathrm{Tl}_{2} \mathrm{Te}+\mathrm{SnS}$ was investigated using differential-thermal analysis, $\mathrm{X}$-ray diffraction and microstructure analysis. The liquidus surface projection, the isothermal section at $520 \mathrm{~K}$ and phase diagrams of four vertical sections were constructed. The liquidus consists of seven primary crystallization fields. The extent of the continuous solid solution range based on the ternary phase $\mathrm{Tl}_{4} \mathrm{SnTe}_{3}$ was estimated.

Thermal analysis / X-ray diffraction/ Microstructure analysis/ Phase diagram / Isothermal section / Solid solution

\section{Introduction}

The $\mathrm{Tl}_{4} X Y_{3}(X=\mathrm{Sn}, \mathrm{Pb} ; Y=\mathrm{S}, \mathrm{Se}, \mathrm{Te})$ compounds are characterized by low thermal conductivity and relatively high thermoelectric figures of merit $Z T$ [1]. Therefore the $\mathrm{Tl}_{4} \mathrm{SnS}_{3}\left(\mathrm{Te}_{3}\right)$ compounds can be considered as perspective materials for thermoelectric devices. To increase the scope of their use, an investigation of the physico-chemical interaction in systems based on the compounds $\mathrm{Tl}_{4} \mathrm{SnS}_{3}\left(\mathrm{Te}_{3}\right)$ seemed promising. The two ternary compounds crystallize in isotypic tetragonal structures [2,3], which indicates a high probability of formation of a solid solution.

\section{Experimental}

Binary thallium(I) and tin(II) sulfides and tellurides were prepared from stoichiometric amounts of highpurity initial elements $(99.99 \mathrm{wt} . \%)$ in evacuated quartz ampoules. The $\mathrm{Tl}_{4} \mathrm{SnS}_{3}, \mathrm{Tl}_{4} \mathrm{SnTe}_{3}$ and $\mathrm{Tl}_{2} \mathrm{Sn}_{2} \mathrm{~S}_{3}$ ternary compounds were obtained from stoichiometric amounts of binary $\mathrm{Tl}_{2} \mathrm{~S}, \mathrm{SnS}$ and SnTe. Multicomponent alloys were synthesized by the direct single-temperature method from binary and ternary sulfides and tellurides in quartz ampoules, which were evacuated to a residual pressure of $0.13 \mathrm{~Pa}$. The highest synthesis temperature was $920 \mathrm{~K}$. After thermal treatment at the highest temperature for
24-36 h the samples were slowly cooled (20-30 K per hour) down to $520 \mathrm{~K}$ and homogenized at this temperature for $168 \mathrm{~h}$. Subsequently the ampoules were quenched in cold water. The phase equilibria were studied by differential thermal analysis (DTA) and X-ray powder diffraction in combination with the simplex method of mathematical modeling of phase equilibria in multicomponent systems. The differential thermal analysis was carried out by means of a device including an $x-y$ recorder PDA-1 and a chromelalumel thermocouple (the linearity of heating and cooling was controlled by a RIF-101 programmer), with an accuracy of $\pm 5 \mathrm{~K}$. X-ray powder diffraction data was collected on a DRON-4 diffractometer $(\mathrm{Cu} K \alpha$ radiation, $\mathrm{Ni}$ filter $)$. The microstructure analysis was carried out with a metallographic microscope Lomo Metam R1. The simplex method of computer simulation of phase equilibria is described in [4].

\section{Results and discussion}

The $\mathrm{Tl}_{2} \mathrm{~S}-\mathrm{Tl}_{2} \mathrm{Te}$ [5] and $\mathrm{SnS}-\mathrm{SnTe}[6]$ systems are of the eutectic type; also in the SnS-SnTe system a eutectoid process takes place (based on the polymorphic transformation of $\mathrm{SnS}$ ) [6]. The quasibinary systems $\mathrm{Tl}_{2} \mathrm{~S}-\mathrm{SnS}$ [7] and $\mathrm{Tl}_{2} \mathrm{Te}-\mathrm{SnTe}[8,9]$ are characterized by the formation of one congruently melting ternary compound: $\mathrm{Tl}_{4} \mathrm{SnTe}_{3}(817 \mathrm{~K})$, and two 
incongruently melting compounds: $\mathrm{Tl}_{4} \mathrm{SnS}_{3}(626 \mathrm{~K})$ and $\mathrm{Tl}_{2} \mathrm{Sn}_{2} \mathrm{~S}_{3}(679 \mathrm{~K})$. A continuous series of solid solutions is formed between the binary thallium(I) telluride and $\mathrm{Tl}_{4} \mathrm{SnTe}_{3}$.

The $\mathrm{Tl}_{4} \mathrm{SnTe}_{3}$ ternary compound, which melts congruently, exists on one of the sides of the $\mathrm{Tl}_{2} \mathrm{~S}+\mathrm{SnTe} \leftrightarrow \mathrm{Tl}_{2} \mathrm{Te}+\mathrm{SnS}$ system. Therefore, it may be that none of the $\mathrm{Tl}_{2} \mathrm{~S}-\mathrm{SnTe}$ or $\mathrm{Tl}_{2} \mathrm{Te}-\mathrm{SnS}$ diagonals of the quadrangle will be stable and the stable sections could be formed by $\mathrm{Tl}_{4} \mathrm{SnTe}_{3}$ (Fig. 1). For this reason the quasibinary sections of the reciprocal $\mathrm{Tl}_{2} \mathrm{~S}+\mathrm{SnTe} \leftrightarrow \mathrm{Tl}_{2} \mathrm{Te}+\mathrm{SnS}$ system must be determined first.

The determination of the quasibinary sections was carried out by phase analysis of samples lying at the intersection of possible quasibinary sections [10]. Three points of intersection of possible quasibinary sections exist in the reciprocal system $\mathrm{Tl}_{2} \mathrm{~S}+\mathrm{SnTe} \leftrightarrow \mathrm{Tl}_{2} \mathrm{~T}+\mathrm{SnSe} \quad$ (Fig. 1). For the determination of the quasibinary sections, alloys corresponding to points 1 and 3 were synthesized and investigated by XRD and microstructure analysis. Based on the results, quasibinarity was established for the two sections $\left(\mathrm{Tl}_{2} \mathrm{~S}-\mathrm{Tl}_{4} \mathrm{SnTe}_{3}, \mathrm{SnSe}-\mathrm{Tl}_{4} \mathrm{SnTe}_{3}\right)$.

The $\mathrm{Tl}_{2} \mathrm{~S}-\mathrm{Tl}_{4} \mathrm{SnTe}_{3}$ system belongs to the Rozeboom type $\mathrm{V}$ (Fig. 2). The system liquidus consists of two parts: the primary crystallization of solid solutions based on $\mathrm{Tl}_{2} \mathrm{~S}$ and $\mathrm{Tl}_{4} \mathrm{SnTe}_{3}$ crystals. The coordinates of the eutectic point are $82 \mathrm{~mol} . \%$ $\mathrm{Tl}_{2} \mathrm{~S}, 605 \mathrm{~K}$ (eutectic process $\mathrm{L} \leftrightarrow \mathrm{Tl}_{2} \mathrm{~S}+\mathrm{Tl}_{4} \mathrm{SnTe}_{3}$ ). At the annealing temperature $(520 \mathrm{~K})$ the solid solution ranges of $\mathrm{Tl}_{2} \mathrm{~S}$ and $\mathrm{Tl}_{4} \mathrm{SnTe}_{3}$ do not exceed 10 and $65 \mathrm{~mol} \%$, respectively. The formation of a wide region of solid solution based on the $\mathrm{Tl}_{4} \mathrm{SnTe}_{3}$ phase was confirmed by the change of the cell parameters according to Vegard's law. Within the solid solution range the lattice parameters change from $a=8.819 \AA$, $c=13.013 \AA$ for $\mathrm{Tl}_{4} \mathrm{SnTe}_{3}$ to $a=8.836 \AA$, $c=12.906 \AA$ for the boundary solid solution (Fig. 3). The results of the microstructure analysis support the XRD data on the phase composition in the system $\mathrm{Tl}_{2} \mathrm{~S}-\mathrm{Tl}_{4} \mathrm{SnTe}_{3}$.

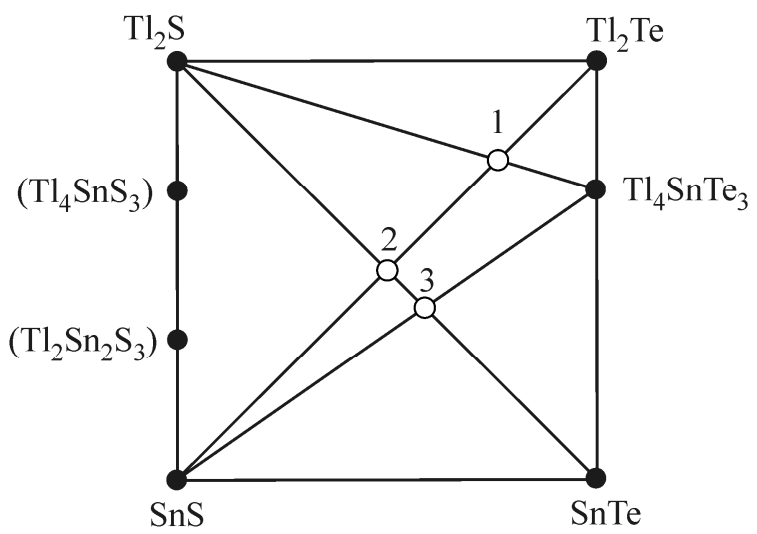

Fig. 1 Possible quasibinary sections in the reciprocal system $\mathrm{Tl}_{2} \mathrm{~S}+\mathrm{SnTe} \leftrightarrow \mathrm{Tl}_{2} \mathrm{Te}+\mathrm{SnS}$.

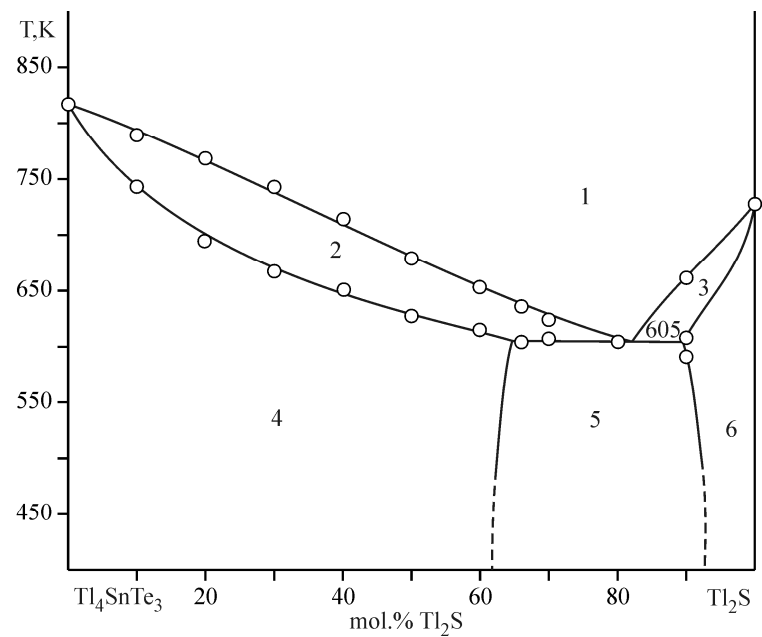

Fig. 2 Phase diagram of the $\mathrm{Tl}_{2} \mathrm{~S}-\mathrm{Tl}_{4} \mathrm{SnTe}_{3}$ system: $1-\mathrm{L}, \quad 2-\mathrm{L}+\mathrm{Tl}_{4} \mathrm{SnTe}_{3}, \quad 3-\mathrm{L}+\mathrm{Tl}_{2} \mathrm{~S}$, $4-\left[\mathrm{Tl}_{4} \mathrm{SnTe}_{3}\right], 5-\mathrm{Tl}_{2} \mathrm{~S}+\mathrm{Tl}_{4} \mathrm{SnTe}_{3}, 6-\left[\mathrm{Tl}_{2} \mathrm{~S}\right]$.

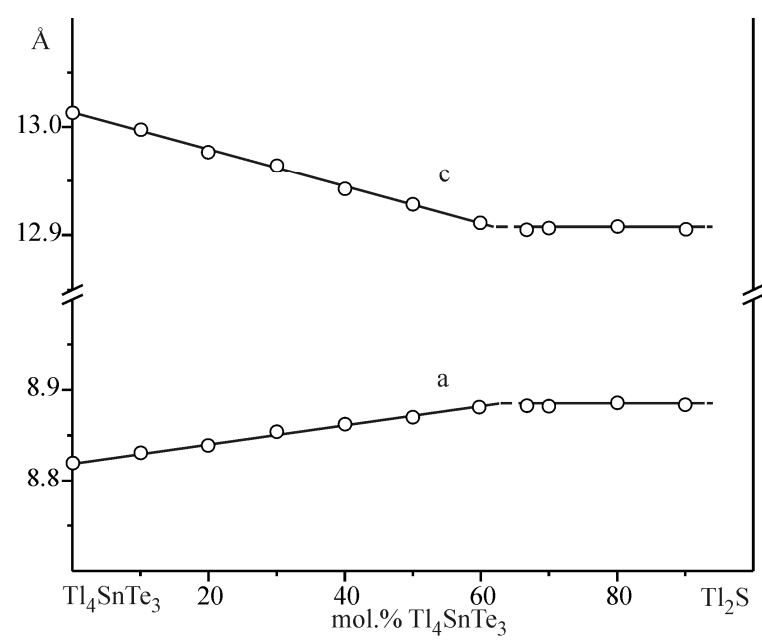

Fig. 3 Lattice parameters of $\mathrm{Tl}_{4} \mathrm{SnTe}_{3}$ in the system $\mathrm{Tl}_{2} \mathrm{~S}-\mathrm{Tl}_{4} \mathrm{SnTe}_{3}$.

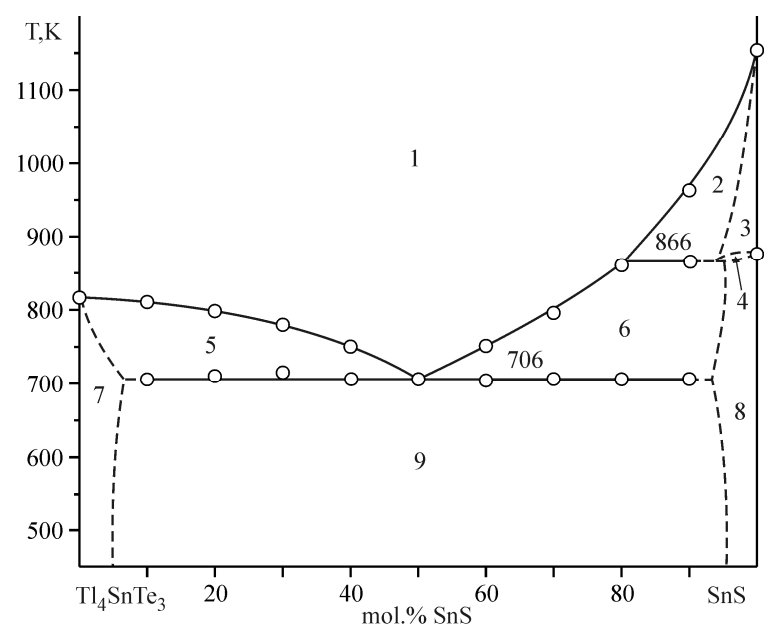

Fig. 4 Phase diagram of the $\mathrm{SnS}_{-} \mathrm{Tl}_{4} \mathrm{SnTe}_{3}$ system: 1 - L, 2 - L+ht-SnS, 3 - [ht-SnS], $4-$ ht-SnS+lt-SnS, $\quad 5-\mathrm{L}+\mathrm{Tl}_{4} \mathrm{SnTe}_{3}$, 6 - L+lt-SnS, $7-\left[\mathrm{Tl}_{4} \mathrm{SnTe}_{3}\right], \quad 8-[\mathrm{lt}-\mathrm{SnS}]$, $9-$ lt-SnS$+\mathrm{Tl}_{4} \mathrm{SnTe}_{3}$. 
The phase diagram of the $\mathrm{SnS}-\mathrm{Tl}_{4} \mathrm{SnTe}_{3}$ system is presented in Fig. 4. The liquidus of the quasibinary system consists of three lines of primary crystallization, which cross in two invariant points with the following coordinates: $50 \mathrm{~mol} \% \mathrm{SnS}, 706 \mathrm{~K}$ (eutectic process $\mathrm{L} \leftrightarrow \mathrm{lt}-\mathrm{SnS}+\mathrm{Tl}_{4} \mathrm{SnTe}_{3}$ ) and $81 \mathrm{~mol} . \%$ $\mathrm{SnS}, 866 \mathrm{~K}$ (metatectic process ht-SnS↔L+lt-SnS). The solid solution ranges based on $\mathrm{Tl}_{4} \mathrm{SnTe}_{3}$ and lt-SnS do not exceed 5 mol. \% a at $520 \mathrm{~K}$.

The $\mathrm{Tl}_{2} \mathrm{Sn}_{2} \mathrm{~S}_{3}-\mathrm{Tl}_{4} \mathrm{SnTe}_{3}$ and $\mathrm{Tl}_{4} \mathrm{SnS}_{3}-\mathrm{Tl}_{4} \mathrm{SnTe}_{3}$ systems are non-quasibinary above the solidus, due to the incongruent melting of the $\mathrm{Tl}_{2} \mathrm{Sn}_{2} \mathrm{~S}_{3}$ and $\mathrm{Tl}_{4} \mathrm{SnS}_{3}$ compounds.

The vertical section of the $\mathrm{Tl}_{2} \mathrm{Sn}_{2} \mathrm{~S}_{3}-\mathrm{Tl}_{4} \mathrm{SnTe}_{3}$ system is presented in Fig. 5. The liquidus consists of two lines that belong to the fields of primary crystallization of $\mathrm{Tl}_{4} \mathrm{SnTe}_{3}$ and lt-SnS, which participates in the peritectic process of formation of $\mathrm{Tl}_{2} \mathrm{Sn}_{2} \mathrm{~S}_{3}$. The lines of primary crystallization intersect in the point with the coordinates 79 mol.\% $\mathrm{Tl}_{2} \mathrm{Sn}_{2} \mathrm{~S}_{3}$, $626 \mathrm{~K}$. The fields of primary crystallization are separated by a three-phase field, L+lt-SnS+ $\mathrm{Tl}_{4} \mathrm{SnTe}_{3}$. At the annealing temperature $(520 \mathrm{~K})$ the solid solution ranges of $\mathrm{Tl}_{4} \mathrm{SnTe}_{3}$ and $\mathrm{Tl}_{2} \mathrm{Sn}_{2} \mathrm{~S}_{3}$ do not exceed 50 and $5 \mathrm{~mol} \%$, respectively. The formation of a wide region of solid solution based on the $\mathrm{Tl}_{4} \mathrm{SnTe}_{3}$ phase is confirmed by the change of the cell parameters according to Vegard's law. The lattice parameters within the solid solution range change from $a=8.819 \AA, c=13.013 \AA$ for $\mathrm{Tl}_{4} \mathrm{SnTe}_{3}$ to $a=8.864 \AA, c=12.933 \AA$ for the boundary solid solution (Fig. 6).

The vertical section of the $\mathrm{Tl}_{4} \mathrm{SnS}_{3}-\mathrm{Tl}_{4} \mathrm{SnTe}_{3}$ system is presented in Fig. 7. The liquidus consists of two lines that belong to the fields of primary crystallization of $\mathrm{Tl}_{4} \mathrm{SnTe}_{3}$ and $\mathrm{Tl}_{2} \mathrm{~S}$, which participates in the peritectic process of formation of the $\mathrm{Tl}_{4} \mathrm{SnS}_{3}$ phase. The lines of primary crystallization intersect in the point with the coordinates $83 \mathrm{~mol} . \%$ $\mathrm{Tl}_{4} \mathrm{SnS}_{3}, 600 \mathrm{~K}$. The fields of primary crystallization are separated by the three-phase field $\mathrm{L}+\mathrm{Tl}_{2} \mathrm{~S}+\mathrm{Tl}_{4} \mathrm{SnTe}_{3}$. The $\mathrm{Tl}_{4} \mathrm{SnS}_{3}-\mathrm{Tl}_{4} \mathrm{SnTe}_{3}$ system is the connecting line of the quasiternary system $\mathrm{Tl}_{2} \mathrm{~S}-\mathrm{Tl}_{4} \mathrm{SnTe}_{3}-\mathrm{SnS}$. It divides the fields of completion of secondary crystallization. This explains the fact that the three-phase region $\mathrm{L}+\mathrm{Tl}_{2} \mathrm{~S}+\mathrm{ht}-\mathrm{Tl}_{4} \mathrm{SnS}_{3}$ borders the single-phase region ht- $\mathrm{Tl}_{4} \mathrm{SnS}_{3}$. At $520 \mathrm{~K}$ the extents of the solid solution ranges based on $\mathrm{Tl}_{4} \mathrm{SnTe}_{3}$ and $\mathrm{lt}_{-} \mathrm{Tl}_{4} \mathrm{SnS}_{3}$ are less than 20 and 10 mol.\%, respectively.

The isothermal section of the $\mathrm{Tl}_{2} \mathrm{~S}+\mathrm{SnTe} \leftrightarrow \mathrm{Tl}_{2} \mathrm{Te}+\mathrm{SnS}$ system includes six singlephase solid solution ranges; four are located in the corners of a quadrangle and two are located between the binary sulfides (Fig. 8).

A projection of the liquidus surface of the reciprocal system $\mathrm{Tl}_{2} \mathrm{~S}+\mathrm{SnTe} \leftrightarrow \mathrm{Tl}_{2} \mathrm{Te}+\mathrm{SnS}$ (Fig. 9) onto the concentration quadrangle was constructed according to the results of the DTA investigation and a computer simulation of the phase equilibria in

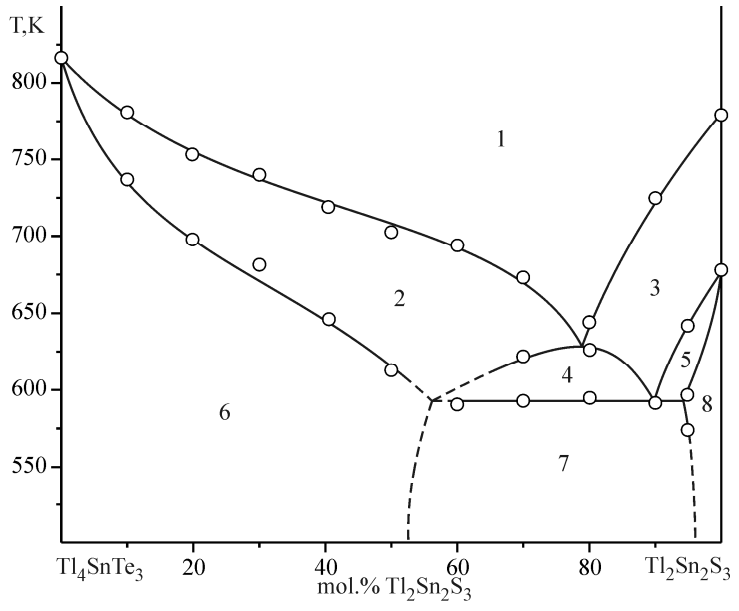

Fig. 5 Phase diagram of the $\mathrm{Tl}_{2} \mathrm{Sn}_{2} \mathrm{~S}_{3}-$ $\mathrm{Tl}_{4} \mathrm{SnTe}_{3}$ system: $\quad 1-\mathrm{L}, \quad 2-\mathrm{L}+\mathrm{Tl}_{4} \mathrm{SnTe}_{3}$, 3 - L+lt-SnS, $\quad 4-\mathrm{L}+1 \mathrm{lt}-\mathrm{SnS}+\mathrm{Tl}_{4} \mathrm{SnTe}_{3}$, 5 - L+lt-SnS+ $\mathrm{Tl}_{2} \mathrm{Sn}_{2} \mathrm{~S}_{3}, \quad 6-\left[\mathrm{Tl}_{4} \mathrm{SnTe}_{3}\right]$, $7-\mathrm{Tl}_{2} \mathrm{Sn}_{2} \mathrm{~S}_{3}+\mathrm{Tl}_{4} \mathrm{SnTe}_{3}, 8-\left[\mathrm{Tl}_{2} \mathrm{Sn}_{2} \mathrm{~S}_{3}\right]$.

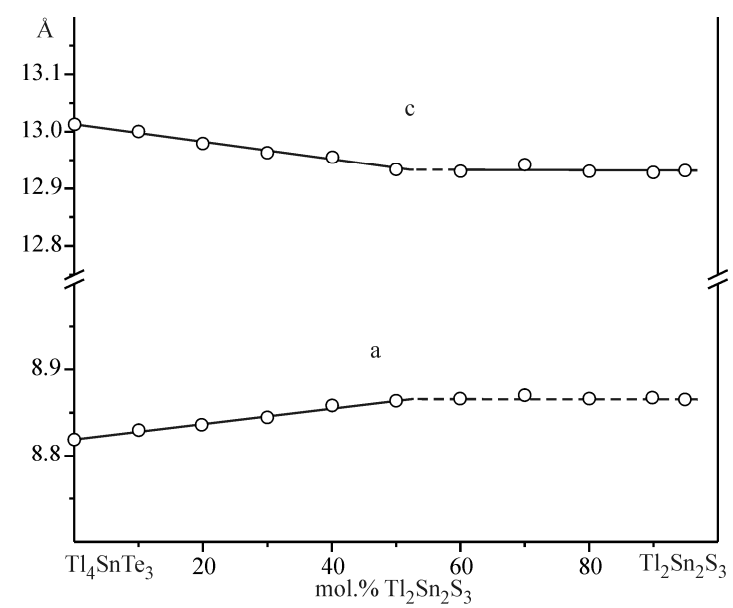

Fig. 6 Lattice parameters of $\mathrm{Tl}_{4} \mathrm{SnTe}_{3}$ in the system $\mathrm{Tl}_{2} \mathrm{Sn}_{2} \mathrm{~S}_{3}-\mathrm{Tl}_{4} \mathrm{SnTe}_{3}$.

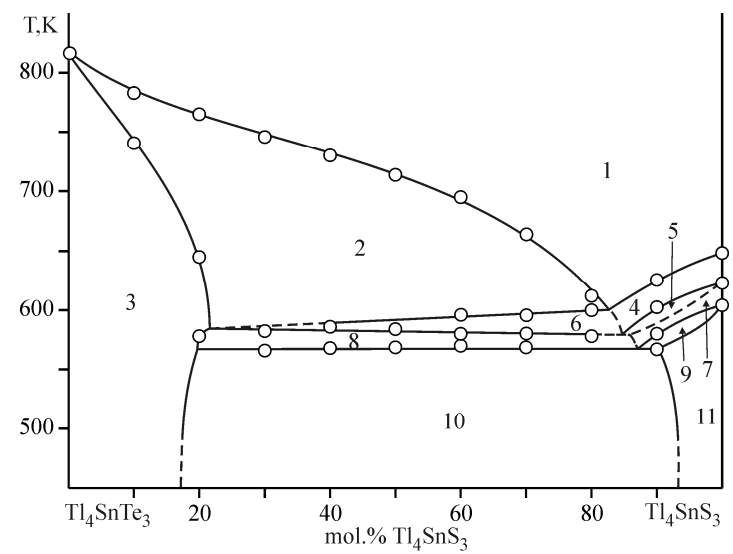

Fig. 7 Phase diagram of the $\mathrm{Tl}_{4} \mathrm{SnS}_{3}-\mathrm{Tl}_{4} \mathrm{SnTe}_{3}$ system: $1-\mathrm{L}, 2-\mathrm{L}+\mathrm{Tl}_{4} \mathrm{SnTe}_{3}, 3-\left[\mathrm{Tl}_{4} \mathrm{SnTe}_{3}\right]$, $4-\mathrm{L}+\mathrm{Tl}_{2} \mathrm{~S}, \quad 5-\mathrm{L}+\mathrm{Tl}_{2} \mathrm{~S}+\mathrm{ht}-\mathrm{Tl}_{4} \mathrm{SnS}_{3}$, $6-\mathrm{L}+\mathrm{Tl}_{2} \mathrm{~S}+\mathrm{Tl}_{4} \mathrm{SnTe}_{3}, \quad 7-\left[\mathrm{ht}-\mathrm{Tl}_{4} \mathrm{SnS}_{3}\right]$, $8-\mathrm{Tl}_{4} \mathrm{SnTe}_{3}+$ ht $-\mathrm{Tl}_{4} \mathrm{SnS}_{3}, 9-$ ht- $\mathrm{Tl}_{4} \mathrm{SnS}_{3}+\mathrm{lt}_{-} \mathrm{Tl}_{4} \mathrm{SnS}_{3}$, $10-\mathrm{Tl}_{4} \mathrm{SnTe}_{3}+\mathrm{lt}-\mathrm{Tl}_{4} \mathrm{SnS}_{3}, 11-\left[\mathrm{lt}_{-} \mathrm{Tl}_{4} \mathrm{SnS}_{3}\right]$. 


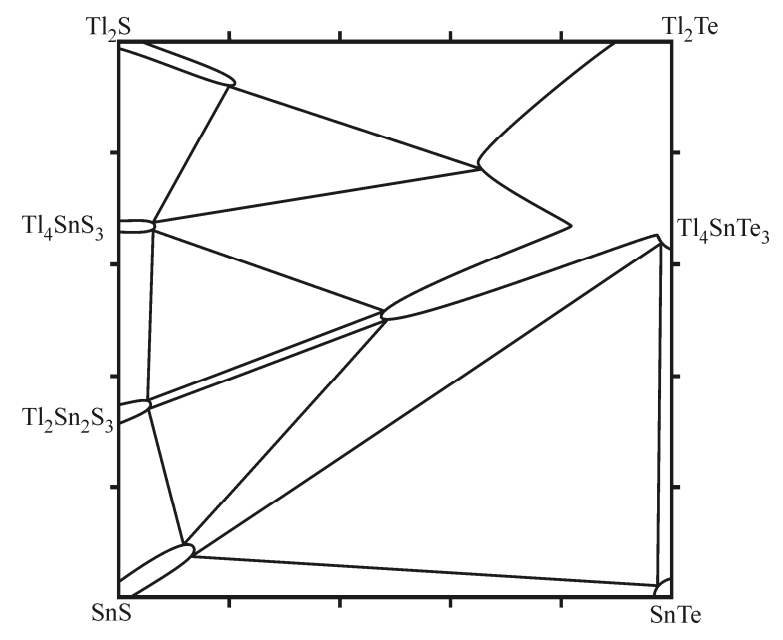

Fig. 8 Isothermal section of the reciprocal system $\mathrm{Tl}_{2} \mathrm{~S}+\mathrm{SnTe} \leftrightarrow \mathrm{Tl}_{2} \mathrm{Te}+\mathrm{SnS}$ at $520 \mathrm{~K}$.

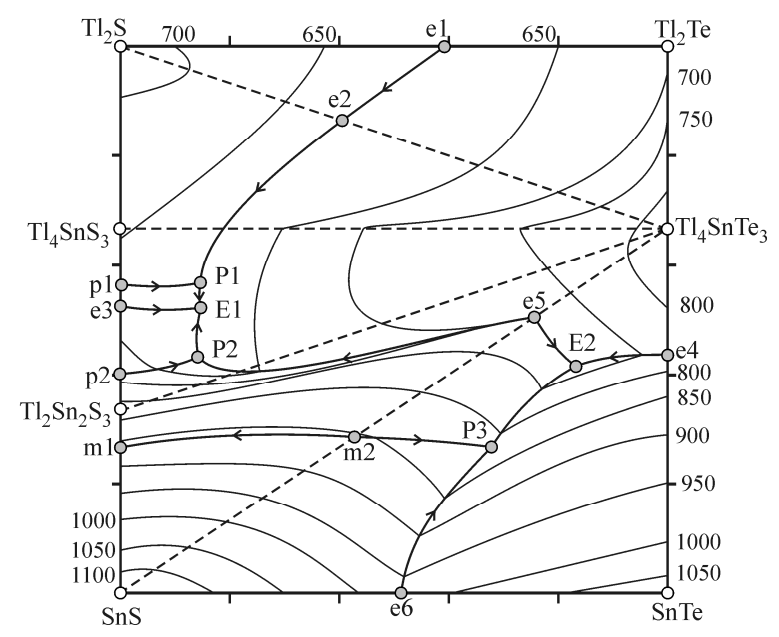

Fig. 9 Projection of the liquidus surface of the reciprocal system $\mathrm{Tl}_{2} \mathrm{~S}+\mathrm{SnTe} \leftrightarrow \mathrm{Tl}_{2} \mathrm{Te}+\mathrm{SnS}$. multicomponent systems by the simplex method. It consists of seven fields of primary crystallization: $\mathrm{Tl}_{2} \mathrm{~S}$ $\left(\mathrm{Tl}_{2} \mathrm{~S}\right.$-e1-e2-P1-p1-Tl $\left.{ }_{2} \mathrm{~S}\right)$, the solid solution based on $\mathrm{Tl}_{2} \mathrm{Te}$ and $\mathrm{Tl}_{4} \mathrm{SnTe}_{3}\left(\mathrm{Tl}_{2} \mathrm{Te}-\mathrm{Tl}_{4} \mathrm{SnTe}_{3}\right.$-e4-E2-e5-P2-E1P1-e2-e1-Tl ${ }_{2} \mathrm{Te}$ ), ht- $\mathrm{Tl}_{4} \mathrm{SnS}_{3} \quad$ (p1-P1-E1-e3-p1), $\mathrm{Tl}_{2} \mathrm{Sn}_{2} \mathrm{~S}_{3}$ (p2-e3-E1-P2-p2), lt-SnS (m1-p2-P2-e5-E2P3-m2-m1), ht-SnS (SnS-m1-m2-P3-e6-SnS), and SnTe (SnTe-e6-P3-E2-e4-SnTe). The fields of primary crystallization are divided by 14 monovariant eutectic, peritectic and metatectic lines. The types and temperatures of the processes in the reciprocal system $\mathrm{Tl}_{2} \mathrm{~S}+\mathrm{SnTe} \leftrightarrow \mathrm{Tl}_{2} \mathrm{Te}+\mathrm{SnS}$ are shown in Table 1 .

The monovariant lines cross in three invariant peritectic and two invariant eutectic points:

P1: $\mathrm{L}+\mathrm{Tl}_{2} \mathrm{~S} \leftrightarrow \mathrm{Tl}_{4} \mathrm{SnTe}_{3}+\mathrm{ht}-\mathrm{Tl}_{4} \mathrm{SnS}_{3} ; 60$ mol.\% $3 \mathrm{Tl}_{2} \mathrm{~S}$, 18 mol.\% $\mathrm{Tl}_{4} \mathrm{SnTe}_{3}, 22$ mol.\% 3SnS, $600 \mathrm{~K}$;

P2: L+lt-SnS↔ $\mathrm{Tl}_{2} \mathrm{Sn}_{2} \mathrm{~S}_{3}+\mathrm{Tl}_{4} \mathrm{SnTe}_{3} ; 31 \mathrm{~mol} . \% \quad 3 \mathrm{Tl}_{2} \mathrm{~S}$, 20 mol.\% $\mathrm{Tl}_{4} \mathrm{SnTe}_{3}, 49 \mathrm{~mol} . \% 3 \mathrm{SnS}, 621 \mathrm{~K}$;

P3: $\quad \mathrm{L}+\mathrm{SnTe} \leftrightarrow \mathrm{lt}-\mathrm{SnS}+\mathrm{Tl}_{4} \mathrm{SnTe}_{3} ; \quad 44 \mathrm{~mol} . \% \quad 3 \mathrm{SnS}$, 20 mol.\% $\mathrm{Tl}_{4} \mathrm{SnTe}_{3}, 36 \mathrm{~mol} . \%$ 3SnTe, $816 \mathrm{~K}$;

E1: $\quad \mathrm{L} \leftrightarrow \mathrm{ht}-\mathrm{Tl}_{4} \mathrm{SnS}_{3}+\mathrm{Tl}_{2} \mathrm{Sn}_{2} \mathrm{~S}_{3}+\mathrm{Tl}_{4} \mathrm{SnTe}_{3} ; \quad 43 \mathrm{~mol} . \%$ $3 \mathrm{Tl}_{2} \mathrm{~S}, 17 \mathrm{~mol} . \% \mathrm{Tl}_{4} \mathrm{SnTe}_{3}, 40 \mathrm{~mol} . \% 3 \mathrm{SnS}, 590 \mathrm{~K}$;

E2: $\quad \mathrm{L} \leftrightarrow \mathrm{lt}-\mathrm{SnS}+\mathrm{SnTe}+\mathrm{Tl}_{4} \mathrm{SnTe}_{3} ; 35 \mathrm{~mol} . \% \quad 3 \mathrm{SnS}$, 36 mol.\% $\mathrm{Tl}_{4} \mathrm{SnTe}_{3}, 29 \mathrm{~mol} . \% 3 \mathrm{SnTe}, 700 \mathrm{~K}$.

New complex compounds were not observed in the reciprocal system $\mathrm{Tl}_{2} \mathrm{~S}+\mathrm{SnTe} \leftrightarrow \mathrm{Tl}_{2} \mathrm{Te}+\mathrm{SnS}$.

\section{Conclusions}

The physico-chemical interactions in the reciprocal system $\mathrm{Tl}_{2} \mathrm{~S}+\mathrm{SnTe} \leftrightarrow \mathrm{Tl}_{2} \mathrm{Te}+\mathrm{SnS}$ were for the first time investigated by differential thermal and microstructure analysis, X-ray powder diffraction and mathematical simulation of phase equilibria in multicomponent systems by the simplex method. The character of the monovariant processes and the temperatures and coordinates of the invariant processes were determined. The existence of solid solutions of the ternary compounds $\mathrm{Tl}_{4} \mathrm{SnS}_{3}$ and $\mathrm{Tl}_{4} \mathrm{SnTe}_{3}$ was established.

Table 1 Type and temperature of the processes in the reciprocal system $\mathrm{Tl}_{2} \mathrm{~S}+\mathrm{SnTe} \leftrightarrow \mathrm{Tl}_{2} \mathrm{Te}+\mathrm{SnS}$.

\begin{tabular}{|c|c|c|}
\hline Monovariant line & Process & Temperature, $\mathrm{K}$ \\
\hline e1-e2 & $\mathrm{L} \leftrightarrow \mathrm{Tl}_{2} \mathrm{~S}+\left[\mathrm{Tl}_{2} \mathrm{Te}+\mathrm{Tl}_{4} \mathrm{SnTe}_{3}\right]$ & $628-605$ \\
\hline e2-P1 & $\mathrm{L} \leftrightarrow \mathrm{Tl}_{2} \mathrm{~S}+\mathrm{Tl}_{4} \mathrm{SnTe}_{3}$ & $605-600$ \\
\hline $\mathrm{p} 1-\mathrm{P} 1$ & $\mathrm{~L}+\mathrm{Tl}_{2} \mathrm{~S} \leftrightarrow \mathrm{ht}-\mathrm{Tl}_{4} \mathrm{SnS}_{3}$ & $626-600$ \\
\hline P1-E1 & $\mathrm{L}+\mathrm{Tl}_{2} \mathrm{~S} \leftrightarrow \mathrm{ht}-\mathrm{Tl}_{4} \mathrm{SnS}_{3}+\mathrm{Tl}_{4} \mathrm{SnTe}_{3}$ & $600-590$ \\
\hline e3-E1 & $\mathrm{L} \leftrightarrow \mathrm{ht}-\mathrm{Tl}_{4} \mathrm{SnS}_{3}+\mathrm{Tl}_{2} \mathrm{Sn}_{2} \mathrm{~S}_{3}$ & $613-590$ \\
\hline e5-P2 & $\mathrm{L} \leftrightarrow \mathrm{lt}-\mathrm{SnS}+\mathrm{Tl}_{4} \mathrm{SnTe}_{3}$ & $706-621$ \\
\hline p2-P2 & $\mathrm{L}+\mathrm{lt}-\mathrm{SnS} \leftrightarrow \mathrm{Tl}_{2} \mathrm{Sn}_{2} \mathrm{~S}_{3}$ & $679-621$ \\
\hline $\mathrm{P} 2-\mathrm{E} 1$ & $\mathrm{~L}+\mathrm{lt}-\mathrm{SnS} \leftrightarrow \mathrm{Tl}_{2} \mathrm{Sn}_{2} \mathrm{~S}_{3}+\mathrm{Tl}_{4} \mathrm{SnTe}_{3}$ & $621-590$ \\
\hline $\mathrm{m} 2-\mathrm{m} 1$ & ht-SnS↔L+lt-SnS & $866-864$ \\
\hline $\mathrm{m} 2-\mathrm{P} 3$ & ht-SnS↔L+lt-SnS & $866-816$ \\
\hline e6-P3 & $\mathrm{L} \leftrightarrow \mathrm{ht}-\mathrm{SnS}+\mathrm{SnTe}$ & $973-816$ \\
\hline e5-E2 & $\mathrm{L} \leftrightarrow \mathrm{lt}-\mathrm{SnS}+\mathrm{Tl}_{4} \mathrm{SnTe}_{3}$ & 706-700 \\
\hline e4-E2 & $\mathrm{L} \leftrightarrow \mathrm{SnTe}+\mathrm{Tl}_{4} \mathrm{SnTe}_{3}$ & $773-700$ \\
\hline P3-E2 & $\mathrm{L}+\mathrm{ht}-\mathrm{SnS} \leftrightarrow \mathrm{lt}-\mathrm{SnS}+\mathrm{SnTe}$ & 739-730 \\
\hline
\end{tabular}




\section{References}

[1] A. Kosuga, K. Kurosaki, H. Muta, S. Yamanaka, MRS Online Proc. Libr. 886 (2006) 063705 (4 p.).

[2] S. Del Bucchia, J.C. Jumas, E. Philippot, M. Maurin, Rev. Chim. Min. 18 (1981) 224-234.

[3] S. Bradtmöller, P. Böttcher, Z. Anorg. Allg. Chem. 619 (1993) 1155-1160.

[4] I.E. Barchiy, Ukr. Khim. Zh. 67 (2001) 18.

[5] M.M. Asadov, M.B. Babanly, A.A. Kuliev, Izv. Akad. Nauk SSSR, Neorg. Mater. 13(8) (1977) 1520-1521.
[6] A.A. Volykhov, V.I. Shtanov, L.V. Yashina, Inorg. Mater. 44(4) (2008) 345-356.

[7] T.A. Malakhovskaya-Rosokha, M.Yu. Sabov, I.E. Barchiy, E.Yu. Peresh, Zh. Neorg. Khim. 56(1) (2011) 122-127.

[8] W. Gawel, E. Zaleska, E. Maskievicz, J. Therm. Anal. 36 (1990) 2323-2327.

[9] T.A. Malakhovska-Rosokha, Nauk. Visn. Uzhhorod. Univ., Ser. Khim. 2(26) (2011) 16-18.

[10] I.E. Barchiy, E.Yu. Peresh, V.M. Rizak, V.O. Khudolij, Heterogeneous Equilibrium, Zakarpattya, Uzhhorod, 2003 (in Ukrainian). 